\title{
Age-Dependent Brain Tissue Hydration, Ca Exchange and their Dose- Dependent Ouabain Sensitivity
}

\author{
Sinerik Ayrapetyan*, Armenuhi Heqimyan and Anna Nikoghosyan
}

UNESCO Chair-Life Sciences, International Postgraduate Educational Center, 31 Acharyan St, 0040 Yerevan, Armenia

\begin{abstract}
Tissue hydration, dose-dependent ${ }^{3} \mathrm{H}$-ouabain binding, ${ }^{45} \mathrm{Ca}^{2+}$ exchange in rat's brain cortex, subcortex and cerebellum were studied in three age groups. Age-dependent tissue dehydration in all three zones of brain was due to inhibition of $\mathrm{Na}^{+} / \mathrm{K}^{+}$pump. The age-dependence of cell hydration in cortex was more expressed. The curve of dose-dependent ouabain binding consists of three components corresponding to $\mathrm{Na}^{+} / \mathrm{K}^{+}$pump isoforms $\left(\alpha_{1} \alpha_{2}\right.$ $\alpha_{3}$ ). Age-dependency of these isoforms was more expressed in cortex than in subcortex and cerebellum. High affinity receptors were depressed in old rats' brain tissues. Initial ${ }^{45} \mathrm{Ca}^{2+}$ uptake in three brain zones of old rats was depressed as compared to that of young animals. Ouabain at $10^{-9} \mathrm{M}$ has activation effect on ${ }^{45} \mathrm{Ca}^{2+}$ uptake, which was also age dependent. Initial ${ }^{45} \mathrm{Ca}^{2+}$ efflux in cortex and subcortex tissue in old rats was significantly depressed as compared to young ones while in cerebellum the opposite age-dependence was observed. The curves of dosedependent ouabain effect on ${ }^{45} \mathrm{Ca}^{2+}$ efflux and cell hydration consist of 6 components. However, close correlation between kinetics of ${ }^{45} \mathrm{Ca}^{2+}$ efflux and cell hydration was not observed. It is suggested that brain tissue dehydration in aged animals is a consequence of $\mathrm{Na}^{+} / \mathrm{K}^{+}$pump dysfunction induced intracellular calcium elevation. It is suggested that $\alpha_{3}$ receptors are functionally connected with intracellular $\mathrm{Ca}^{2+}$ buffering systems through intracellular signaling systems and their dysfunction in aged brain is a consequence of $\left[\mathrm{Ca}^{2+}\right]_{\mathrm{i}}$ increase. Obtained data allow us to conclude that endogen nanomolar ouabain-like species circulating in mammals' blood removing $\mathrm{Ca}^{2+}$ from cells could have a beneficial effect on brain of old animals.
\end{abstract}

\section{Introduction}

Although the important physiological role of water in cell functional activity is well known and widely accepted, its messenger role in the generation of various diseases including aging-induced memory loss and the increase of nerve disorders risk has not been paid an adequate attention by researchers. It is known that aging-induced memory loss and the increase of the risk of nerve disorders are accompanied by tissue dehydration. However, whether the age-induced cell dehydration is the primary risk factor for age-related nerve disorders is not clear. The role of cell hydration in the memory processes, as well as the role of cell volume controlling metabolic mechanisms in neuronal dysfunctions has not been investigated in detail.

As the intracellular osmotic pressure in normal cells exceeds the extracellular one, then dysfunction of metabolic energy generating pathways or membrane selective permeability disturbance at first could bring to cell swelling. As the activity of intracellular proteins and gene expressing systems strongly depends on hydration, the latter could be considered as a critical factor for the regulation of intracellular metabolic activity. Our early works showed that membrane proteins having enzymatic, receptor and channel-forming properties can be in functionally active and inactive (reserve) states, the ratio of which is changed depending on cell hydration [1]. Cell swelling (membrane unpacking), leads to the increase of functionally active membrane receptors' [2,3], membrane enzyme molecules' [4] and ionic channels' number in membrane [5], while its dehydration (membrane packing) has an opposite effect. On the basis of these data cell swelling can be considered as primary messenger switching on intracellular signaling system through which the protective reaction of cells is realized.

Among the number of mechanisms involved in cell volume regulation $\mathrm{Na}^{+} / \mathrm{K}^{+}$pump has fundamental role, because $\mathrm{Na}^{+}$ gradient serves as an energy source for a number of secondary ionic transporters, such as $\mathrm{Na}^{+} / \mathrm{Ca}^{2+}, \mathrm{Na}^{+} / \mathrm{H}^{+}$, sugars, amino acids and osmolytes [6]. It is known that there are two enzyme systems actively involved in metabolic regulation of cell volume associated with cation transport across membrane surface. In this process transport ATPases are indeed the translocating structure and are fueled by the free energy derived from ATP hydrolysis while kinases may regulate translocation via phosphorylation of the transporter molecules through the phosphorylation of associated regulatory structures. The close talking between these two enzyme systems is realized through the intracellular signaling systems, the dysfunction of which leads to generation of cell pathology. The latter is accompanied by corresponding changes of cell hydration. As $\mathrm{Na}^{+} / \mathrm{K}^{+}$pump is the most ATP-utilizing machine in cell, it serves as a main regulator of all other ionic pumps' and kinases' activity. Therefore factors able to change the balance between ATP hydrolysis and ATP production system (in mitochondria) by changing $\mathrm{Na}^{+} / \mathrm{K}^{+}$pump activity could switch on the intracellular signaling systems-induced modulation of cell katabolic and anabolic process. Therefore, the dysfunction of $\mathrm{Na}^{+} / \mathrm{K}^{+}$pump controlling cell hydration can be considered as a common gate for cell pathology. However, the nature of mechanism through which $\mathrm{Na}^{+} / \mathrm{K}^{+}$pump dysfunction leads to apoptosis and proliferation inhibition in excitable cells stays unclear.

The second ionic transporting mechanism in cell membrane having a crucial role in cell volume regulation is $\mathrm{Na}^{+} / \mathrm{Ca}^{2+}$ exchange [7-10]. It is known that there is a close correlation between electrogenic $\mathrm{Na}^{+} / \mathrm{K}^{+}$

*Corresponding author: Sinerik Ayrapetyan, UNESCO Chair-Life Sciences International Postgraduate Educational Center, 31 Acharyan St, 0040 Yerevan, Armenia, Tel: +374-10-624170; Fax: +374-10-624170; E-mail: info@biophys.am

Received May 04, 2012; Accepted May 26, 2012; Published May 28, 2012

Citation: Ayrapetyan S, Heqimyan A, Nikoghosyan A (2012) Age-Dependent Brain Tissue Hydration, Ca Exchange and their Dose-Dependent Ouabain Sensitivity. J Bioequiv Availab 4: 060-068. doi:10.4172/jbb.1000114

Copyright: (c) 2012 Ayrapetyan S, et al. This is an open-access article distributed under the terms of the Creative Commons Attribution License, which permits unrestricted use, distribution, and reproduction in any medium, provided the original author and source are credited. 
pump and electrogenic $\mathrm{Na}^{+} / \mathrm{Ca}^{2+}$ exchange which have been described since pioneering work by Baker et al. [11]. At present a close correlation between these two ion transporting mechanisms on the level of different $\mathrm{Na}^{+} / \mathrm{K}^{+}$pump isoforms is known, thanks to great contribution of one of co-authors of this work doctor Blaustein's group, who identified and characterized different isoforms of $\mathrm{Na}^{+} / \mathrm{K}^{+}$pump $[12,13]$.

As $\mathrm{Na}^{+} / \mathrm{K}^{+}$pump has a crucial role in cell adaptation process, aging can be considered as a consequence of $\mathrm{Na}^{+} / \mathrm{K}^{+}$pump dysfunction $[14,10]$, which leads to the down regulation $\mathrm{Ca}^{2+}$ homeostasis [1518]. Small enhancement of intracellular $\mathrm{Ca}^{2+}$ concentration leads to the inactivation of $\mathrm{Na}^{+} / \mathrm{K}^{+} / \mathrm{Mg}^{2+}$-ATPase [19]. It is known that $\mathrm{Na}^{+} /$ $\mathrm{K}^{+}$-ATPase has three isoforms of catalytic ( $\alpha$ ) subunit having different affinities to cardiac glycoside ouabain: $\alpha_{1}$ (low affinity), $\alpha_{2}$ (middle affinity) and $\alpha_{3}$ (high affinity). They also have a different localization in cells: $\alpha_{1}$ is ubiquitously distributed over the surfaces of cells, while high ouabain affinity isoforms are confined to a reticular distribution within the cellular membrane that paralleled underlying endoplasmic or sarcoplasmic reticulum, with $\mathrm{Na}^{+} / \mathrm{Ca}^{2+}$ exchanger protein. The expression of these isoforms is age-dependent [20-25]. While the role of low-affinity receptors as a working molecule for $\mathrm{Na}^{+} / \mathrm{K}^{+}$pump is well established [25-27], the functional role of high-affinity receptors is still discussable [13]. Detailed investigations [28-30] showed that $\mathrm{Na}^{+} /$ $\mathrm{Ca}^{2+}$ exchange is regulated through the high-affinity ouabain receptors, while $\mathrm{Na}^{+} / \mathrm{K}^{+}$pump by means of low-affinity ones. The detailed mechanism of correlation between functions of $\alpha_{3}$ and $\alpha_{2}$ pump subunit and $\mathrm{Na}^{+} / \mathrm{Ca}^{2+}$ exchange and their functional significance in norm and pathology are not clear.

Therefore, considering all the facts mentioned, the study of agedependent ouabain sensitivity of cell hydration and $\mathrm{Na}^{+} / \mathrm{Ca}^{2+}$ exchange could bring us close in understanding the role of different isoforms of $\mathrm{Na}^{+} / \mathrm{K}^{+}$pump in the regulation of cell hydration. For this purpose the effect of rats' aging $(6,18$ weeks and 18 months) on the cell hydration and its ouabain sensitivity, dose-dependent ouabain binding with cell membrane and ${ }^{45} \mathrm{Ca}^{2+}$ uptake and efflux in brain cortex, subcortex and cerebellum were studied.

\section{Materials and Methods}

All procedures performed on animals were carried out following the protocols approved by Animal Care and Use Committee of Life Sciences International Postgraduate Educational Centre (LSIPEC, Yerevan, Armenia).

\section{Animals}

Experiments were performed on three separate groups of male albino rats: young (6 weeks old), adult (18 weeks old) and old (18 months old) weighing 35-40 g, 100-120 g and 250-300 g, respectively. Animals were regularly examined, kept under control of the veterinary in LSIPEC and reserved in a specific pathogen free animal room under optimum conditions of $12 \mathrm{~h} \mathrm{light/dark}$ cycle, at temperature of $22 \pm$ $2^{\circ} \mathrm{C}$, a relative humidity of $50 \%$ and were fed ad libitum on a standard lab chow and water.

For definition of initial water content five animals from each group were chosen and their data were considered as control after intraperitoneally injected physiological solution (PS). In subsequent experimental parts of investigation the same number of animals was used. The brain tissue hydration was provoked by single application of interperitioneal injection of $3 \mathrm{ml} \mathrm{DW}$, isotonic $\left(0.9 \% \mathrm{NaCl}_{2}\right)$ and hypertonic (2 M Mannitol containing) PS. Study of ${ }^{45} \mathrm{Ca}^{2+}$ uptake and the rate constant of ${ }^{45} \mathrm{Ca}$ efflux from brain tissues was performed on young and old animals $(n=5)$. All data was received from three independent experiments.

\section{Chemicals}

Tyrode's physiological solution (PS) containing (in $\mathrm{mM}$ ) 137 $\mathrm{NaCl}, 5.4 \mathrm{KCl}, 1.8 \mathrm{CaCl}_{2}, 1.05 \mathrm{MgCl}_{2}, 5 \mathrm{C}_{6} \mathrm{H}_{12} \mathrm{O}_{6}, 11.9 \mathrm{NaHCO}_{3}, 0.42$ $\mathrm{NaH}_{2} \mathrm{PO}_{4}$ and adjusted to $\mathrm{pH} 7.4$ with $\mathrm{NaOH}$ was used. For increasing the PS osmolarity the non-metabolizing substance- Mannitol $\left[\mathrm{C}_{6} \mathrm{H}_{8}(\mathrm{OH})_{6}\right.$, mol. wt. 182.18], $2 \mathrm{M}$ was dissolved in the saline $(0.9$ $\left.\% \mathrm{NaCl}_{2}\right)$. All chemicals were obtained from "Medisar" Industrial Chemical Importation Company (Yerevan, Armenia). K-free solution was consisted of $5.4 \mathrm{mM} \mathrm{NaCl}$ instead of $5.4 \mathrm{mM} \mathrm{KCl} .{ }^{45} \mathrm{Ca}^{2+}$ with specific activity: $40 \mathrm{mCi} / \mathrm{ml}$ was added in $\mathrm{K}$-free solution containing $68.5 \mathrm{mM}(50 \%) \mathrm{NaCl}$ and used for tissues' samples enriching. Radioactive ${ }^{3} \mathrm{H}$-ouabain with specific activity $25.34 \mathrm{Ci} / \mathrm{mM}$ and non radioactive one (PerkinElmer, Massachusetts, USA) from $10^{-11} \mathrm{M}$ to $10^{-4} \mathrm{M}$ concentrations dissolved in physiological solution was used for intraperitoneal injections and tissues' incubation. The volume of injected solution was adjusted according to the weight of animals.

\section{Tissue preparation}

It is well known that anesthetics with different chemical and pharmacological profiles [31-33] significantly affect metabolic processes which play an important role in regulation of cell volume $[12,34]$. Therefore, in present experiments the animals were sharply immobilized by freezing method (dipping their noses into liquid nitrogen for 3-4 sec) and decapitated [35]. After such procedure the full absence of somatic reflexes on extra stimuli was recorded. Investigated tissues were isolated and dissected into the samples weighing from 50 to $70 \mathrm{mg}$. Both for cortex, subcortex and cerebellum tissues 25 samples were chosen for each experimental group.

\section{Definition of water content of brain tissues}

Water content of brain tissues tissue was performed by traditional "tissue drying" method. After measuring the tissue wet weight (w.w.) it was dried in thermostat (Factory of Medical Equipment, Odessa, Ukraine) during $24 \mathrm{~h}$ at $105^{\circ} \mathrm{C}$ for determination of dry weight (d.w.). The quantity of water in $1 \mathrm{~g}$ of d.w. of tissue was counted by the following equation: (w.w. - d.w.)/d.w.

\section{Counting of ${ }^{3} \mathrm{H}$-ouabain receptors in membrane}

${ }^{3} \mathrm{H}$-ouabain solution is usually used to estimate the number of membrane ouabain receptors. It is assumed that each binding site (receptor) in membrane binds one ouabain molecule. Dried tissues' samples were homogenized in $50 \mu \mathrm{l}$ of $68 \% \mathrm{HNO}_{3}$ solution, then 2 $\mathrm{ml}$ of Bray's scintillation fluid was added and chemoluminescence of samples was quantified with 1450 MicroBeta liquid scintillation counter (Wallac Oy, Turku, Finland). Number of ouabain receptors was defined per mg of dry weight.

\section{Measurement of ${ }^{45} \mathrm{Ca}^{2+}$ uptake and ${ }^{45} \mathrm{Ca}^{2+}$ efflux rate constant}

Measuring of ${ }^{45} \mathrm{Ca}^{2+}$ uptake was made in vivo conditions. For this purpose in Tyrode's physiological solution $0.0115 \mathrm{mM} \mathrm{CaCl}_{2}$ from 1.8 $\mathrm{mM}$ was substituted by ${ }^{45} \mathrm{Ca}^{2+}$ the radioactivity of which was $11.2 \mathrm{mCi} / \mathrm{l}$. Then young and old animals were intraperitoneally injected by 0.187 $\mathrm{mCi} / \mathrm{g}$ of body weight. After $30 \mathrm{~min}$ they were decapitated and brain samples were incubated for $30 \mathrm{~min}$ in PS (as a control) and $10^{-9} \mathrm{M}, 10^{-4}$ $\mathrm{M}$ ouabain solutions. After that all samples were dried in thermostat 
during $24 \mathrm{~h}$ at $105^{\circ} \mathrm{C}$. After definition of samples' dry weight they were homogenized in $50 \mu \mathrm{l}$ of $68 \% \mathrm{HNO}_{3}$ solution, then $2 \mathrm{ml}$ of Bray's scintillation fluid was added and chemiluminescence's of samples was quantified with 1450 MicroBeta liquid scintillation counter (Wallac Oy, Turku, Finland). ${ }^{45} \mathrm{Ca}^{2+}$ content was defined per mg of dry mass.

For measurement of ${ }^{45} \mathrm{Ca}^{2+}$ efflux all samples of brain tissues were incubated during $60 \mathrm{~min}$ in $\mathrm{K}$-free (containing $50 \% \mathrm{NaCl}$ ) solution where ${ }^{45} \mathrm{Ca}^{2+}$ was added $\left(10.77 \mu \mathrm{l}{ }^{45} \mathrm{Ca}^{2+}\right.$ for $100 \mathrm{ml} \mathrm{K}$-free solution) for tissue enriching by ${ }^{45} \mathrm{Ca}^{2+}$. Then ${ }^{45} \mathrm{Ca}^{2+}$-enriched samples were washed three times (in K-free solution) for 10.5 and $5 \mathrm{~min}$, respectively, for removing the extracellular ${ }^{45} \mathrm{Ca}^{2+}$. Brain tissues samples were divided on two parts. First 25 samples were placed in thermostat during $24 \mathrm{~h}$ at $105^{\circ} \mathrm{C}$. Second 25 samples were incubated in ouabain solution during $30 \mathrm{~min}$. Then all samples were dried in thermostat during $24 \mathrm{~h}$ at $105^{\circ} \mathrm{C}$. After definition of samples dry weight they were homogenized in 50 $\mu \mathrm{l}$ of $68 \% \mathrm{HNO}_{3}$ solution, then $2 \mathrm{ml}$ of Bray's scintillation fluid was added and chemiluminescence's of samples was quantified with 1450 MicroBeta liquid scintillation counter (Wallac Oy, Turku, Finland). ${ }^{45} \mathrm{Ca}^{2+}$ content was defined per mg of dry mass and the rate constant of ${ }^{45} \mathrm{Ca}^{2+}$ efflux was calculated as an exited part of absorbed ${ }^{45} \mathrm{Ca}^{2+}$ for control and experimental data.

\section{Statistic analysis}

The Microsoft Excel and Sigma-Plot (Version 8.02A, NY, USA) were used for data analysis. Significance in comparison with the control group was calculated with Student's paired t-test with the following symbols $\left({ }^{*} \mathrm{P}<0.05 ;{ }^{* *} \mathrm{P}<0.01 ;{ }^{* *} \mathrm{P}<0.001\right)$.

\section{Results}

Before the main study of the ouabain effect on brain tissue hydration four independent experiments were performed to determine the dynamics of hydration changes in brain tissue in three age groups. The results showed variability between the mean values of initial hydration in each age group. However, the dynamics of change for the mean hydration value was the same for each age group in all experiments. The overall mean hydration value in all three age groups is very close to the data presented for the fourth group of experiments. On Figure 1 the initial water content in tissue of three brain zones in three age groups is presented. As can be seen the initial water content in tissues of young animals was higher than in adult and old ones. It worth to note that initial water content in cortex tissue was higher than in subcortex and cerebellum tissues in all age groups.

To estimate the age-dependent dynamics of $\mathrm{Na}^{+} / \mathrm{K}^{+}$pumpdependent cell hydration changes in three zones of brain tissue in all age groups under the effect of $10^{-4} \mathrm{M}$ ouabain concentration were studied. For these experiments new animal groups (young, adult and aged) were taken. In each group five animals were decapitated after 30 min of $10^{-4} \mathrm{M}$ ouabain intraperitoneal injection and water content was determined in brain zones of all investigated animals. Data presented on Figure 2 demonstrate that ouabain at concentration of $10^{-4} \mathrm{M}$ has total hydration effect on all brain zones of three age groups (Figure 2A$2 \mathrm{C}$ ) as compared to sham data. However, $10^{-4} \mathrm{M}$ ouabain induced tissue hydration was less pronounced in young animals than in adult and old animals. These data are in harmony with literature data that in early postnatal period of development the $\mathrm{Na}^{+} / \mathrm{K}^{+}$pump expression is rather weak and it increases during periods of maturation [12]. Therefore, a more pronounced ouabain-induced hydration of brain tissues in adult and old animals as compared to young ones can be explained by more expressed $\mathrm{Na}^{+} / \mathrm{K}^{+}$pump in maturated animals [36,37]. Observed

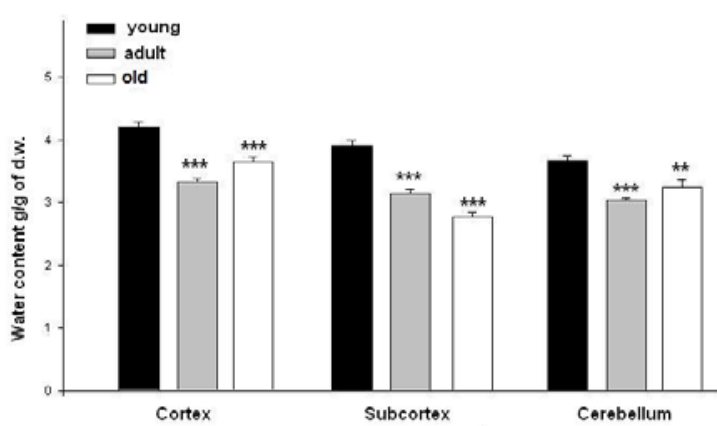

Figure 1: Age dependent initial level of water content in young, adult and aged rats' brain tissues (cortex, subcortex and cerebellum). Ordinate indicates the mean value of tissues' water content. As a control the data of young group animals was taken. Error bars indicate the standard error of the mean (SEM) for three independent experiments. The symbols $\left(^{* *}\right)$ and $\left({ }^{* *}\right)$ indicate $\mathrm{P}<0.01$ and $\mathrm{P}<0.001$, respectively.
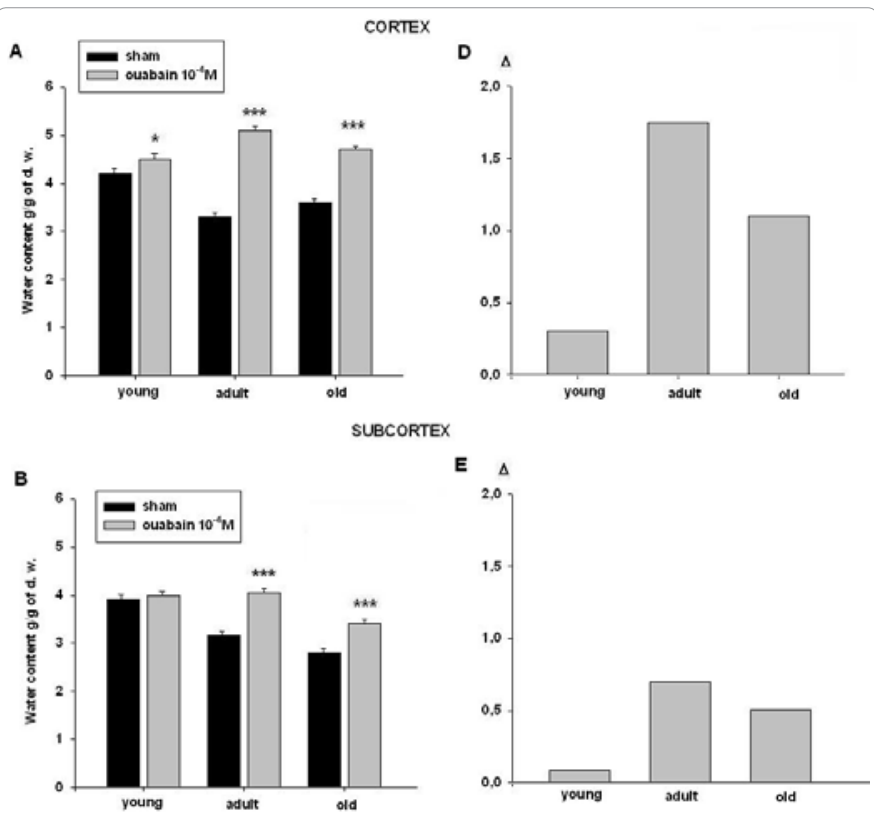

CEREBELLUM
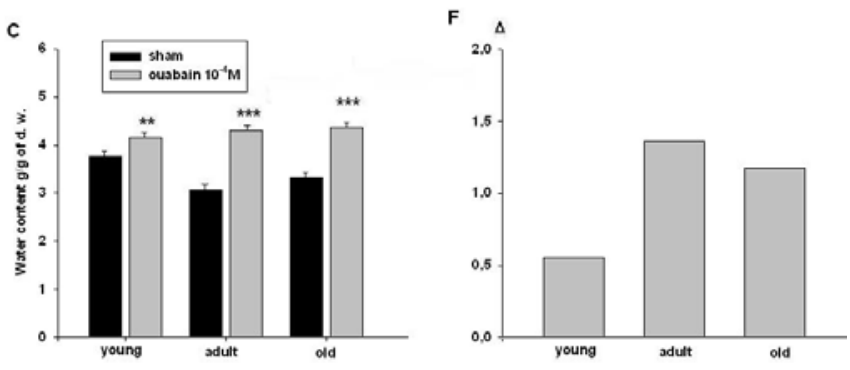

Figure 2: Age dependent change of brain tissues water content $(A, B, C)$ in young, adult and aged animals after 30 min ouabain $10^{-4} \mathrm{M}$ intraperitoneal injection. Ordinates indicate the mean value of tissues' water content. On figure right side $(D, E, F)$ delta $(\Delta)$ determines the difference between water content received from sham and ouabain poisoned data. As a sham data the mean values showed on Figure 2 was taken. Error bars indicate the standard error of the mean (SEM) for three independent experiments. The symbols $\left(^{*}\right),\left(^{* *}\right)$ and $\left.{ }^{* * *}\right)$ indicate $\mathrm{P}<0.05, \mathrm{P}<0.01$ and $\mathrm{P}<0.001$, respectively. A difference which is not statistically significant means that $P>0.05$. 
differences of brain tissues hydration in three groups of animals can be more clearly seen on right colon of Figure 2D-2F where the differences $(\Delta)$ between water content of sham and ouabain-poisoned animals are presented. It is worth to note that in adult animals cortex tissue hydration is higher than that of subcortex and cerebellum.

In the next series of experiments the correlation between dosedependent ${ }^{3} \mathrm{H}$-ouabain binding and brain tissue hydration in three ages' animal groups were studied, which would let us to clarify the role of different isoforms of catalytic a subunit in determination of observed age-dependent changes of tissue hydration.

As shown in Figure 3A-3C on dose-dependent ${ }^{3} \mathrm{H}$-ouabain binding curves of all investigated brain tissues in young, adult and old animals three types of ouabain receptors having different kinetics of binding $\left(10^{-11}-10^{-9} \mathrm{M}, 10^{-9}-10^{-7} \mathrm{M}\right.$ and $\left.10^{-7}-10^{-4} \mathrm{M}\right)$ can be distinguished. These data are confirmed by literature data on the existence of three types $\left(\boldsymbol{\alpha}_{3}, \boldsymbol{\alpha}_{2}\right.$, and $\left.\boldsymbol{\alpha}_{1}\right)$ of $\mathrm{Na}^{+} / \mathrm{K}^{+}$-ATPase $\boldsymbol{\alpha}$ catalytic subunit in excitable cell membrane [11]. As shown on the Figure 3, the kinetics of investigated brain tissues is similar in young (Figure 3A) and old (Figure 3C) age groups. However, in adult group the kinetics of ouabain binding of cortex tissue where higher hydration was observed than in subcortex and cerebellum (Figure 2) the number of ouabain molecules is much higher in cortex tissue, than in subcortex and cerebellum (Figure 3B). It should be noted that in cortex tissue of adult animals ${ }^{3} \mathrm{H}$-ouabain binding kinetics is distinctly higher expressed in range of $\boldsymbol{\alpha}_{3}$ isoform $\left(10^{-11}-10^{-9} \mathrm{M}\right)$. The reversed dose-dependent decrease of ouabain binding in all three zones of brain tissues in young and less pronounced in tissues of subcortex and cerebellum of adults seems strange and difficult for interpretation. In old rats the dose dependency of ouabain binding is not visible in all three zones of brain tissues (Figure 3C), which indicates on their dysfunction.

It is known that ouabain binding depends both on the number and the affinity of receptors. Previous experiments performed on snail nerve ganglia showed that the number of ouabain receptors increases with cell swelling and decreases with cell shrinkage [4]. To find out the existence of such correlation between cell hydration and number of ouabain receptors in cell membrane of rats' brain tissue a series of experiments on the influence of different osmolarity solutions was performed on adult rats. As it can be seen on Table 1, the intraperitoneal injection of distilled water leads to the increase of brain tissue hydration in all three investigated zones of brain; while the same volume of hypertonic solution (mannitol) injection leads to cell hydration. A close correlation between cell hydration and number of ${ }^{3} \mathrm{H}$-ouabain binding molecules was observed. Distilled water-induced cell hydration was accompanied by increase, while hypertonic solution-induced cell dehydration-by decrease of the number of ouabain molecules binding with membrane. It is interesting to note that cortex tissue hydration and the number of ouabain receptors are more sensitive to both hypo- and hypertonic solution-induced stress than that of subcortex and cerebellum. From these data can be concluded that cell dehydration induced decrease of ouabain receptors in membrane can serve as one of mechanisms determining the weakening of $\mathrm{Na}^{+} / \mathrm{K}^{+}$pump activity (Figure 2 ) in aged animals (Figure 1).

In order to find out the individual role of observed three populations of ouabain receptors with different affinity $\left(\boldsymbol{\alpha}_{3}, \boldsymbol{\alpha}_{2}\right.$, and $\left.\boldsymbol{\alpha}_{1}\right)$ in determination of age-dependent cell dehydration the dosedependent effect of ouabain on cell hydration in brain tissues of young and old animals was studied.
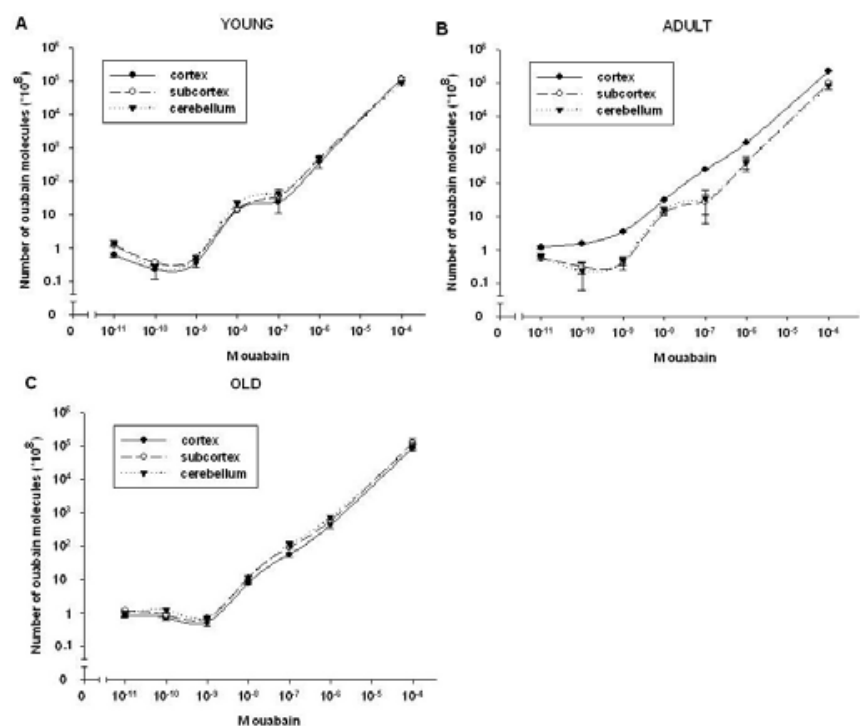

Figure 3: Number of ouabain molecules as a function of ${ }^{3} \mathrm{H}$-ouabain different concentrations in brain cortex, subcortex and cerebellum tissues of young (A), adult (B) and old (C) animal groups. Abscissas indicate ${ }^{3} \mathrm{H}$-ouabain concentrations, ordinates are logarithmic and define number of ouabain molecules in tissues. Each point of curve is the mean \pm SD for three independent experiments. Error bars of each point are not detected because being blended with it.

This study has shown that even extremely low ouabain concentrations $\left(10^{-14}-10^{-9} \mathrm{M}\right)$ have a strong modulation effect on cell hydration in all three age animal groups: the activation of high affinity ouabain receptors causes dehydration of brain tissue in young and older rats, hydration - in adults. The dose-dependent ouabain effect on tissue hydration in young and old animals is clearly seen on Figure 4A$4 \mathrm{C}$, on which the dependence of ouabain induced effect is compared with control one. As can be seen on this figure the curve of the dosedependent ouabain effect on brain tissue hydration in range of $10^{-11}$ $10^{-4}$ consists of 6 components, namely $10^{-11}-10^{-10}, 10^{-10}-10^{-9}, 10^{-9}-10^{-8}$, $10^{-8}-10^{-7}, 10^{-7}-10^{-6}, 10^{-6}-10^{-4}$; whereas the dose-dependent ouabain binding curve consists of 3 components. It is interesting to note that in old animals these components are more pronounced than in young ones. From these data can be concluded that there may be minimum 6 mechanisms involved in cell volume regulation having different ouabain sensitivity. Such heterogeneity within the family of $\mathrm{Na}^{+} / \mathrm{K}^{+} \alpha_{1}$ $\alpha_{2}, \alpha_{3}$ isoforms indicates that ouabain receptors having the same affinity are functionally connected with different metabolic mechanisms involved in cell volume regulation.

As brain aging leads to the increase of intracellular $\mathrm{Ca}$ ions concentration [38] which has a crucial role in regulation of membrane receptors affinity to agonists, the study of the correlation between cell hydration and ${ }^{45} \mathrm{Ca}^{2+}$ uptake and efflux as well as their ouabain sensitivity in young and old rats was the subject for the next series of experiments.

In Figure $5 \mathrm{~A}-5 \mathrm{C}$ data on ${ }^{45} \mathrm{Ca}^{2+}$ uptake by brain tissue in normal and $10^{-9}, 10^{-4} \mathrm{M}$ ouabain poisoned young and old rats are presented. As can be seen from these data, in all investigated tissues of young animals the intensity of ${ }^{45} \mathrm{Ca}^{2+}$ uptake is higher than that of old ones. In $10^{-9} \mathrm{M}$ ouabain poisoned young and old animals ${ }^{45} \mathrm{Ca}^{2+}$ uptake is higher as compared to control ones. The $10^{-4} \mathrm{M}$ ouabain concentration influence is much higher than that of $10^{-9} \mathrm{M}$ in cortex and cerebellum 
in both ages' animals (Figure 5A and 5C) while in subcortex of young rats it was depressed (Figure 5B). The differences of ${ }^{45} \mathrm{Ca}^{2+}$ uptake agedependence in different zones of normal and poisoned animals' brain tissues can be seen more clearly on Figure 5D-5F.

It is known that $\mathrm{Ca}^{2+}$ uptake could take place by two pathways: by potential activated $\mathrm{Ca}^{2+}$ channels and by $\mathrm{Na}^{+} / \mathrm{Ca}^{2+}$ exchange in reverse mode [30]. As low concentration ouabain is unable to inactivate $\mathrm{Na}^{+} /$ $\mathrm{K}^{+}$pump and depolarize the membrane, the potential-dependent $\mathrm{Ca}^{2+}$ channels induced uptake of ions is excluded. Therefore $\mathrm{Na}^{+} / \mathrm{Ca}^{2+}$ exchange in reverse mode can be the only pathway through which low ouabain could stimulate ${ }^{45} \mathrm{Ca}^{2+}$ uptake. These data are in harmony with our previous data performed on snail neuronal ganglia on the activation effect of low concentration ouabain $\left(<10^{-7} \mathrm{M}\right)$ on ${ }^{22} \mathrm{Na}$ efflux and ${ }^{45} \mathrm{Ca}^{2+}$ uptake $[4,39]$.

As energy source for driving $\mathrm{Na}^{+} / \mathrm{Ca}^{2+}$ exchange in reverse mode is electrochemical potential for $\mathrm{Ca}^{2+}\left(\mathrm{E}_{\mathrm{Ca}}\right)$ which exceeds the electrochemical potential for $\mathrm{Na}^{+}\left(\mathrm{E}_{\mathrm{Na}}\right)$, low ouabain-induced activation
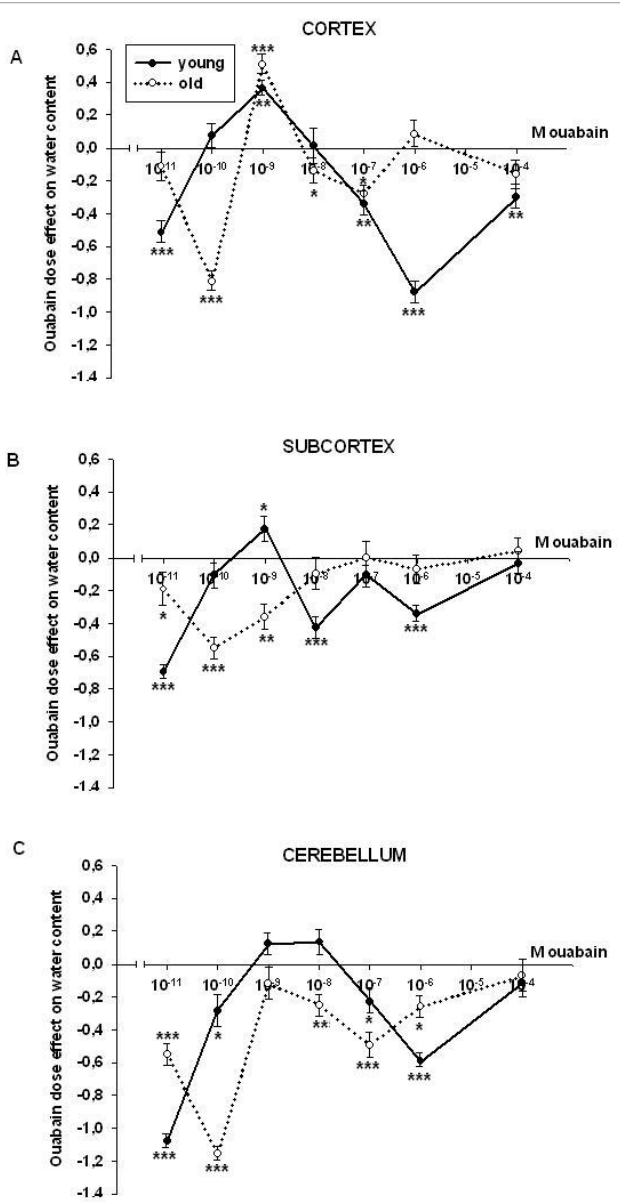

Figure 4: The effect of ouabain injection $\left(10^{-11}-10^{-4} \mathrm{M}\right)$ on cortex $(A)$, subcortex (B) and cerebellum (C) tissues' hydration in two age groups. Curves with continuous line-effect of ouabain in young animals. Curves with dotted lineeffect of ouabain in the same tissues of old animals. Each point on lines shows the difference between hydration mean values of control and ouabain poisoned animals. Abscissas indicate ouabain doses, ordinates - difference between hydration mean values of control and ouabain poisoned animals. Error bars indicate the standard error of the mean (SEM) for three independent experiments. The symbols $\left.\left({ }^{*}\right),{ }^{* *}\right)$ and $\left({ }^{* * *}\right)$ indicate $P<0.05, P<0.01$ and $\mathrm{P}<0.001$, respectively. A difference which is not statistically significant means that $\mathrm{P}>0.05$.
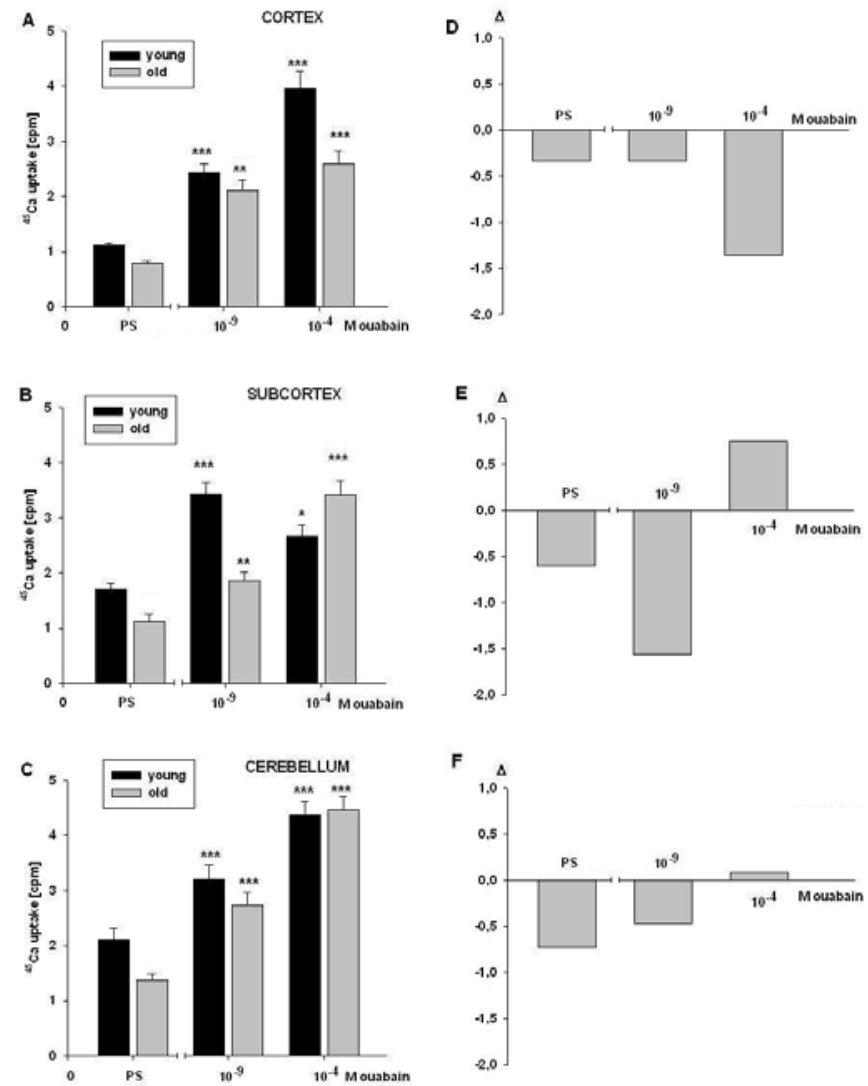

Figure 5: The effect of ouabain injection $\left(10^{-9}, 10^{-4} \mathrm{M}\right)$ on cortex, subcortex and cerebellum tissues' ${ }^{45} \mathrm{Ca}^{2+}$ uptake (A-C) in two age groups. Abscissas of A-F indicate doses of ouabain (PS injection, i.e. OM ouabain, $10^{-9}, 10^{-4} \mathrm{M}$ ). Ordinates of A-C indicate ${ }^{45} \mathrm{Ca}^{2+}$ uptake content counting per minute, ordinates of D-F delta $(\Delta)$ determines the difference between ${ }^{45} \mathrm{Ca}^{2+}$ uptake in two age groups. Error bars indicate the standard error of the mean (SEM) for three independent experiments. The symbols $\left({ }^{*}\right),\left({ }^{* *}\right)$ and $\left({ }^{* * *}\right)$ indicate $P<0.05, P<0.01$ and $P<0.001$, respectively. A difference which is not statistically significant means that $\mathrm{P}>0.05$.

of ${ }^{45} \mathrm{Ca}^{2+}$ uptake can be explained by increasing $\mathrm{E}_{\mathrm{Ca}}$ because of $\mathrm{Ca}^{2+}$ adsorption by intracellular structure or by activation $\mathrm{Ca}^{2+}$ pump.

The study of dose-dependent effect of ouabain on ${ }^{45} \mathrm{Ca}^{2+}$ efflux from young and older rats' brain tissues indicates that the initial rate constant of ${ }^{45} \mathrm{Ca}^{2+}$ efflux from cortex and subcortex tissues in young animals is much higher than in old ones, while in cerebellum tissue it is higher in old animals (Figure 6A). Figure 6B shows the difference between values of ${ }^{45} \mathrm{Ca}^{2+}$ efflux from the investigated brain zones in old and young animals. It is interesting to note that in cerebellum age dependence of ${ }^{45} \mathrm{Ca}^{2+}$ efflux has reverse character in contrast to cortex and subcortex tissues (Figure 6B). As in case of dose-dependent ouabain effect on brain tissue hydration (Figure 4) the curve of dosedependent ouabain effect on ${ }^{45} \mathrm{Ca}^{2+}$ efflux also consists of 6 components (Figure 7). However, there is no direct correlation between kinetics of dose-dependent ouabain effects on ${ }^{45} \mathrm{Ca}^{2+}$ efflux and cell hydration. The activation of ${ }^{45} \mathrm{Ca}^{2+}$ efflux which is realized by $3 \mathrm{Na}^{+} / 1 \mathrm{Ca}^{2+}$ exchange predicts the increase of cell hydration. However, its activation by $10^{-10} \mathrm{M}$ ouabain (Figure 7) was accompanied by sharp dehydration (Figure 4). In young rats' cortex tissue ouabain at all concentrations has inhibitory effect on ${ }^{45} \mathrm{Ca}^{2+}$ efflux from the cells, while in old animals ouabain has activation effect on it (Figure 7). It is interesting to note that in range $10^{-11}-10^{-8} \mathrm{M}$ ouabain i.e. in zones of high affinity receptors $\left(\alpha_{3}\right.$ and $\left.\alpha_{2}\right)$ 
the dose-dependent dynamics of ${ }^{45} \mathrm{Ca}^{2+}$ efflux in young and older rats has opposite character while at higher concentrations its dynamics has similar character (Figure 7A).

In subcortex tissue (Figure 7B) the dynamics of dose dependent ouabain effect on ${ }^{45} \mathrm{Ca}^{2+}$ efflux in young and old animals has similar character, but the rate constant of ${ }^{45} \mathrm{Ca}^{2+}$ efflux was much higher in older animals than in young ones. In contrast to cortex and subcortex tissues the dynamics of ${ }^{45} \mathrm{Ca}^{2+}$ efflux from cerebellum tissue has highly variable character (Figure 7C). Ouabain at all concentrations has inhibitory effect on ${ }^{45} \mathrm{Ca}^{2+}$ efflux in old animals while in young animals this effect is observed only at $10^{-11} ; 10^{-8}$ and $10^{-6} \mathrm{M}$. Such reverse age dependency of ${ }^{45} \mathrm{Ca}^{2+}$ efflux in cerebellum tissue of normal (Figure 6) and ouabain poisoned animals (Figure 7) seems very interesting and could serve as a special subject for a more detailed investigation.

\section{Discussion}

At present it is a proven fact that metabolic control of cell volume is a dynamic parameter regulating cell's various functions $(1,6,40$ 42). It is widely recognized that although neural cell swelling can be observed under physiological conditions, for example as a result of neurotransmission or intense neuronal discharge (4,43-45), larger changes are encountered during pathological conditions, including aging. It is known also that neuronal dehydration in older adults is a reliable predictor of increasing frailty, progressive deterioration in cognitive function and an overall reduction in quality of life [46-49]. There are a number of hypotheses on regard of detailed role of agedependent cell dehydration in deterioration in cognitive function of brain. However, because of our weak knowledge on the detailed metabolic cell volume controlling mechanism(s) dysfunction of which brings to neuronal dehydration in aging animal is the main barrier in understanding the real functional role of neuronal dehydration in dysfunction of brain cognitive function in aging. As $\mathrm{Na}^{+} / \mathrm{K}^{+}$pump dysfunction can be considered as one of the reasons for aging in present work we have made an attempt to find out the individual role of different pump isoforms having different affinity to ouabain $\left(\alpha_{1}, \alpha_{2}, \alpha_{3}\right)$ [12] in generation of age-dependent dehydration in rats' brain tissues.

Data obtained in present work indicate that water content of brain cortex tissues is higher than that of subcortex and cerebellum in all age groups (Figure 1). Although initial water content of investigated tissues of young rats is higher than in adult ones (Figure 1A-1C), $10^{-4}$ $\mathrm{M}$ ouabain poisoning-induced cell hydration which is due to $\mathrm{Na}^{+} / \mathrm{K}^{+}$ pump inhibition is significantly less than in maturated animals (Figure

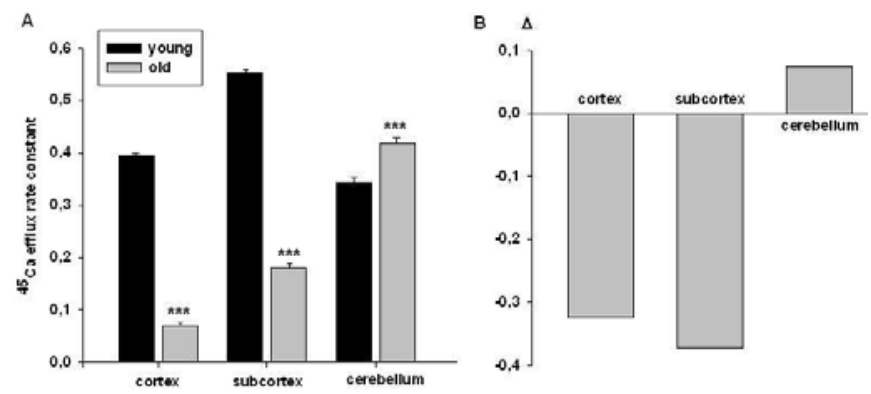

Figure 6: Rate constant of ${ }^{45} \mathrm{Ca}^{2+}$ efflux from cortex, subcortex and cerebellum tissues in young and old animals (A). On B the difference $(\Delta)$ between mean values of ${ }^{45} \mathrm{Ca}^{2+}$ efflux in young and old animal groups is shown. Error bars indicate the standard error of the mean (SEM) for three independent experiments. The symbol $\left.{ }^{* * *}\right)$ indicates $\mathrm{P}<0.001$.
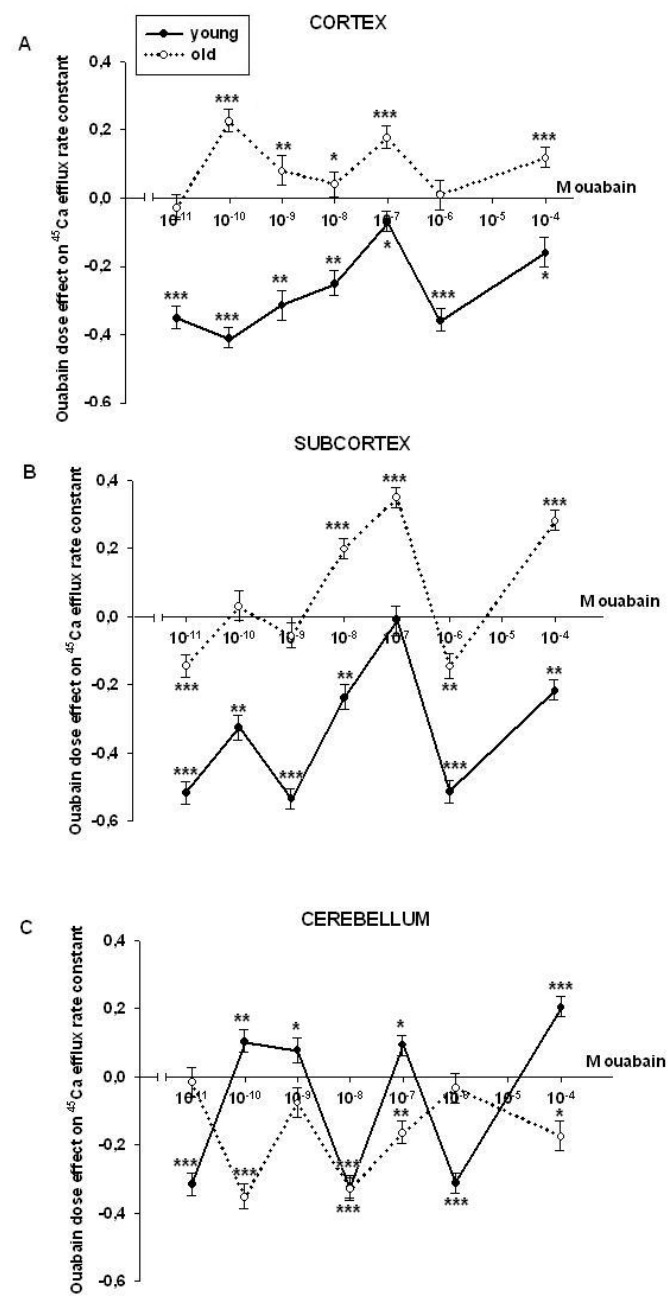

Figure 7: The effect of ouabain injection $\left(10^{-11}-10^{-4} \mathrm{M}\right)$ on rate constant of ${ }^{45} \mathrm{Ca}^{2+}$ efflux from cortex (A), subcortex (B) and cerebellum (C) tissues' in two age groups. Curves with continuous line - effect of ouabain in young animals. Curves with dotted line - effect of ouabain in the same tissues of old animals. Each point on lines shows the difference between mean values of control and ouabain poisoned animals. Abscissas indicate ouabain doses, ordinates difference between rate constant mean values of control and ouabain poisoned animals. Error bars indicate the standard error of the mean (SEM) for three independent experiments. The symbols $\left({ }^{*}\right),\left({ }^{* *}\right)$ and $\left({ }^{* * *}\right)$ indicate $\mathrm{P}<0.05$ $P<0.01$ and $P<0.001$, respectively. A difference which is not statistically significant means that $P>0.05$.

2D-2F). The data that age-dependent changes of ouabain-induced brain tissues' hydration have a bell-shaped dynamics (young<adults $>$ aged) are in harmony with literature data on the reciprocal relationship between the expression of $\mathrm{Na}^{+} / \mathrm{K}^{+}$pump and $\mathrm{Na}^{+} / \mathrm{Ca}^{2+}$ exchanger proteins in neuronal development. In prenatal and early postnatal periods the expression proteins of $\mathrm{Na}^{+} / \mathrm{Ca}^{2+}$ exchanger prevails, while by maturating the expression $\mathrm{Na}^{+} / \mathrm{K}^{+}$pump protein increases, reaching its maximum in adults and then intervenes its dysfunction in aging [12]. From this point of view the high water content in brain tissues of young animals can be explained by higher activity of electrogenic $\mathrm{Na}^{+} /$ $\mathrm{Ca}^{2+}$ exchange, working in stechiometry of $3 \mathrm{Na}^{+} / 1 \mathrm{Ca}^{2+}[10]$ while the brain tissue dehydration in adult animals can be explained by activation of electrogenic $\mathrm{Na}^{+} / \mathrm{K}^{+}$pump $[36,37]$. Therefore, it is predictable that $10^{-4} \mathrm{M}$ ouabain induced inhibition of $\mathrm{Na}^{+} / \mathrm{K}^{+}$pump leads to lower hydration in brain tissues of young than maturated animals (Figure 2). 
It is known that brain aging causes increase of $\left[\mathrm{Ca}^{2+}\right]_{\mathrm{i}}$ ions [38] leading to reverse functioning of $\mathrm{Na}^{+} / \mathrm{Ca}^{2+}$ exchange [10], having a dehydration effect on cells [7]. The reverse functioning of $\mathrm{Na}^{+} / \mathrm{Ca}^{2+}$ exchange from one side could have cell dehydration and from the other side cell hydration effect through $\left[\mathrm{Ca}^{2+}\right]_{i}$-induced $\mathrm{Na}^{+} / \mathrm{K}^{+}$pump inhibition [21]. Therefore, in aging animals $\mathrm{Na}^{+} / \mathrm{Ca}^{2+}$ exchange would have a prevailing role in the regulation of neuronal volume because of dysfunction of $\mathrm{Na}^{+} / \mathrm{K}^{+}$pump.

Obtained data on age-dependent kinetics of dose-dependent ouabain binding indicate that in young animals there is a strict difference between kinetics of ouabain receptors having different affinity to ouabain, which correspond to three $\mathrm{Na}^{+} / \mathrm{K}^{+}$pump isoforms $\left(\alpha_{1} \alpha_{2} \alpha_{3}\right)$ described in literature [11]. It is worth to note that data on age-dependent changes of ouabain molecules' number could not be considered as marker for changes of expressed quantity of ouabain receptors in membrane, because of age-dependent membrane lipid composition changes, having strong modulation effect on membrane receptors affinity to agonist. However the dose-dependent kinetics of ouabain binding with $\alpha_{1} \alpha_{2} \alpha_{3}$ receptors in brain tissue of three animal ages, could give information on age-dependent changes of their functional activity.

It seems extremely interesting that the process of maturation leads to significant changes in ouabain binding in brain cortex while the changes in subcortex and cerebellum of adult animals was negligible (Figure 3B), as in case of hydration (Figure 2D). It can be explained by aging-induced increase of brain cognition function in maturation, in which cortex has a crucial role. The disappearance of dose-dependent ouabain binding with $\alpha_{3}$ receptors $\left(10^{-11}-10^{-9} \mathrm{M}\right)$ in the investigated tissues of aged animals could be interpreted as a marker for the dysfunction of these receptors. Such dysfunction can be explained by the depression of their affinity in result of age-dependent increase of intracellular Ca ions [38], having inhibitory effect on $\mathrm{Na}^{+} / \mathrm{K}^{+}$-ATPase activity [21]. These data correspond to literature data that $\alpha_{3}$ receptors have a higher affinity to intracellular Ca ions than $\alpha_{2}$ and $\alpha_{1}$ receptors [12].

Data obtained on the close correlation between cell hydration and number of ouabain receptors in membrane (Table 1) allow us to suggest that aging alongside with decreasing of ouabain receptors affinity could bring also to decrease of ouabain receptors number as a result of brain tissue dehydration. The fact that aging-induced dehydration could have a more pronounced depressing effect on $\alpha_{3}$ receptors than on others indicates their deeper localization in membrane as compared to $\alpha_{2}$ and $\alpha_{1}[21,42]$. The fact that osmo sensitivity of $\alpha_{3}$ receptors in cortex is higher than in subcortex and cerebellum allows us to speculate on the possible role of these receptors in determination of single neuronal memory.

Because of high sensitivity of cell hydration to ouabain in present work was possible to indicate that the family of $\alpha_{1} \alpha_{2} \alpha_{3}$ ouabain receptors is not homogenic, i.e. there can be distinguished minimum 6 components, namely sensitive to $10^{-11}-10^{-10} \mathrm{M}, 10^{-10}-10^{-9} \mathrm{M}, 10^{-9}$. $10^{-8} \mathrm{M}, 10^{-8}-10^{-7} \mathrm{M}, 10^{-7}-10^{-6} \mathrm{M}, 10^{-6}-10^{-4} \mathrm{M}$ (Figure 4). These data are in harmony with literature data on the existence of caveolae in cell membrane having different metabolic functions [50].

The fact that direct correlation between cell hydration and ouabain binding was absent in the described experiments (Figure 4) indicates that the age-dependent depression of ouabain binding cannot be a result of cell dehydration-induced decrease of ouabain receptors' number in membrane only, there are other age-dependent factors leading to decrease of ouabain receptor's affinity to agonist. Obtained data indicate also the involvement of intracellular mechanisms of cell volume regulation having different sensitivity to ouabain. The literature data on higher ouabain sensitivity of intracellular Ca buffering structure [51,52] allow us to consider this buffering system responsible for agedependent changes of dose-dependent ouabain effect on cell hydration. This suggestion is confirmed by the study of dose-dependent ouabain effect on ${ }^{45} \mathrm{Ca}^{2+}$ uptake (Figure 5) and efflux (Figure 6 and 7).

Pioneering work by Baker et al. [10] performed on perfused axon from Loligo forbasi, described in detail the correlation between $\mathrm{Na}^{+} / \mathrm{K}^{+}$pump and $\mathrm{Na}^{+} / \mathrm{Ca}^{2+}$ exchange. There were distinguished two components of ${ }^{22} \mathrm{Na}$ efflux: ouabain sensitive $\left(\mathrm{Na}^{+} / \mathrm{K}^{+}\right.$pump) and ouabain non sensitive $\left(\mathrm{Na}^{+} / \mathrm{Ca}^{2+}\right.$ exchange) components. Our work performed on whole (non-perfused) and preliminary ${ }^{22} \mathrm{Na}$ enriched snail neurones has shown that ouabain high concentration $\left(>10^{-7} \mathrm{M}\right)$ has inhibitory effect on ${ }^{22} \mathrm{Na}$ efflux as in axon, but its lower concentrations $\left(<10^{-7} \mathrm{M}\right)$ have activation effect on ${ }^{22} \mathrm{Na}$ efflux [4], which is due to the activation of $\mathrm{Na}^{+} / \mathrm{Ca}^{2+}$ exchange in reverse mode [39]. It is obvious that such differences of ouabain sensitivity of $\mathrm{Na}^{+} / \mathrm{Ca}^{2+}$ exchange in internally perfused squid axon and whole snail neuron can be explained by different membrane properties of squid axon and snail neuronal membrane or by ouabain-induced changes of $\mathrm{Ca}$ ions' gradient on

\begin{tabular}{|c|c|c|c|c|c|c|c|c|c|c|}
\hline Brain Zones & $\begin{array}{c}\text { Control } 1 \text { (intact } \\
\text { animals) }\end{array}$ & $\begin{array}{c}D W \\
\text { injection }\end{array}$ & $\Delta \%$ & $P$ value & $\begin{array}{c}\text { Control } 2 \\
(P S \\
\text { injection) }\end{array}$ & $\Delta \%$ & $P$ value & $\begin{array}{l}\text { Mannitol } \\
\text { injection }\end{array}$ & $\Delta \%$ & $P$ value \\
\hline \multicolumn{11}{|c|}{ Hydration [water cont. g/g d.w.] (mg.) } \\
\hline Cortex & $2.82 \pm 0.05$ & $4.4 \pm 0.074$ & $\uparrow 42$ & $P=0,4$ & $3.1 \pm 0.0374$ & $\uparrow 10$ & $P=0,0000078$ & $2.28 \pm 0.022$ & $\downarrow 26.5$ & $P=0,00039$ \\
\hline Stem & $3.09 \pm 0.075$ & $3.5 \pm 0.072$ & $\uparrow 34$ & $P=0,3$ & $2.6 \pm 0.055$ & $\downarrow 15.8$ & $P=0,000025$ & $2.28 \pm 0.018$ & $\downarrow 12.3$ & $P=0,0006$ \\
\hline Cerebellum & $2.75 \pm 0.041$ & $3.2 \pm 0.08$ & $\uparrow 23$ & $P=0,8$ & $2.6 \pm 0.06$ & $\downarrow 5.5$ & $P=0,0001$ & $2.145 \pm 0.019$ & $\downarrow 17.5$ & $P=0,053$ \\
\hline \multicolumn{11}{|c|}{$\times 10^{7}$ molecule g/ d.w. } \\
\hline Cortex & $19 \pm 0.18$ & $30.4 \pm 0.027$ & $\uparrow 45$ & $P=0,011$ & $20.9 \pm 0.13$ & $\uparrow 10$ & $P=0,0000067$ & $15.2 \pm 0.8$ & $\downarrow 27$ & $P=0,00025$ \\
\hline Stem & $17 \pm 0.22$ & $19.8 \pm 0.021$ & $\uparrow 38$ & $P=0,013$ & $14.3 \pm 0.16$ & $\downarrow 15.8$ & $P=0,000033$ & $12.84 \pm 0.5$ & $\downarrow 10.2$ & $P=0,0001$ \\
\hline Cerebellum & $22 \pm 0.2$ & $25.69 \pm 0.04$ & $\uparrow 23$ & $P=0,1$ & $20.87 \pm 0.3$ & $\downarrow 5.1$ & $P=0,0005$ & $16.05 \pm 0.9$ & $\downarrow 23$ & $P=0,034$ \\
\hline
\end{tabular}

Table 1: Correlation between brain tissues hydration and the number of ouabain molecules in experiments with intraperitoneally injected distilled water (DW), physiological solution (PS) and mannitol. 
membrane by modulation Ca-buffering intracellular systems which were removed in axonal experiments. Data obtained in presented experiments on clear age-dependent depressing of ${ }^{45} \mathrm{Ca}^{2+}$ uptake (Figure 5) and ${ }^{45} \mathrm{Ca}^{2+}$ efflux (Figure 6 and 7) in brain tissues of rats conform the second explanation. As initial level of intracellular Ca ions is higher in brain tissues of old animals than in that of young ones [38] data obtained in present work on the lower intensity of ${ }^{45} \mathrm{Ca}^{2+}$ uptake in brain tissues of older animals than that of young ones is predictable (Figure $5)$. Data that low ouabain concentration $\left(10^{-9} \mathrm{M}\right)$ which is unable to inactivate $\mathrm{Na}^{+} / \mathrm{K}^{+}$pump, but activates ${ }^{45} \mathrm{Ca}^{2+}$ uptake in brain cortex and cerebellum tissues, exclude the explanation of this effect by increase of intracellular $\mathrm{Na}$ ions [53]. It is known that ${ }^{45} \mathrm{Ca}^{2+}$ uptake by neuron can be realized also by potential-dependent $\mathrm{Ca}$ ionic channels [7]. The fact that $10^{-9} \mathrm{M}$ ouabain concentration has more pronounced activation effect on ${ }^{45} \mathrm{Ca}^{2+}$ uptake than $10^{-4} \mathrm{M}$ ouabain, when membrane potential is depolarized because of inactivation of electrogenic $\mathrm{Na}^{+} / \mathrm{K}^{+}$pump [54], excludes involvement of potential activated $\mathrm{Ca}$ channels in the realization of ouabain-induced ${ }^{45} \mathrm{Ca}^{2+}$ uptake stimulation. Therefore, as the difference between electrochemical gradients of these two ions $\left(\mathrm{E}_{\mathrm{C}}\right.$ and $\mathrm{E}_{\mathrm{Na}}$ ) serves energy for $\mathrm{Na}^{+} / \mathrm{Ca}^{2+}$ exchange, the activation of $\mathrm{Na}^{+} / \mathrm{Ca}^{2+}$ exchange in reverse mode could be explained only by the increase of $\mathrm{E}_{\mathrm{Ca}}$ as a result of cell intracellular $\mathrm{Ca}$ adsorption. The fact that low-ouabain induced activation effect on ${ }^{45} \mathrm{Ca}^{2+}$ uptake in old animals weakens can be considered as a result of aging induced depression of $\mathrm{Ca}$ adsorption properties of intracellular structure because of their being Ca-saturated by high $\left[\mathrm{Ca}^{2+}\right]_{\mathrm{i}}[38]$. It is interesting that aging has a more pronounced inhibitory effect on ${ }^{45} \mathrm{Ca}$ efflux in subcortex than cortex tissue, while in cerebellum activation of ${ }^{45} \mathrm{Ca}^{2+}$ efflux was observed (Figure 6B).

Although the dysfunction of ${ }^{45} \mathrm{Ca}^{2+}$ efflux in aging animals can be considered as a proven fact, its reason is not clear yet. It is known that $\mathrm{Ca}$ ions can be removed from cells by two mechanisms: Ca-pump and $\mathrm{Na}^{+} / \mathrm{Ca}^{2+}$ exchange in forward mode. Notwithstanding the affinity of Ca-pump is higher than $\mathrm{Na}^{+} / \mathrm{Ca}^{2+}$ exchange because the latter has incomparably higher rate than Ca-pump, it is suggested that $\mathrm{Na}^{+} / \mathrm{Ca}^{2+}$ exchange has a more essential role in regulation of $[\mathrm{Ca}]_{\mathrm{i}}$ homeostasis $[12,34]$. There is a great number of literature data about the crucial role of $\alpha_{3} \alpha_{2}$ isoforms of $\mathrm{Na}^{+} / \mathrm{K}^{+}$in regulation of $\mathrm{Na}^{+} / \mathrm{Ca}^{2+}$ exchange. However, the detailed mechanism of their interaction stays unclear.

The existence of 6 components on curve of dose-dependent ouabain effect on ${ }^{45} \mathrm{Ca}^{2+}$ efflux (Figure 7), as in case of cell hydration (Figure 4), indicates that in the background of dose-dependent ouabaininduced modulation of cell hydration and ${ }^{45} \mathrm{Ca}^{2+}$ efflux are common intracellular mechanism(s) having the same age-dependent character. Data on heterogeneity within the family of previously described three $a$ isoforms and clear age-dependency are new and could serve as a target for detailed investigation of metabolic mechanisms, dysfunction of which leads to cell pathology, including aging.

The fact that ouabain has a reverse dose-dependent activation on ${ }^{45} \mathrm{Ca}^{2+}$ uptake (Figure 5) and inhibition on ${ }^{45} \mathrm{Ca}^{2+}$ efflux (Figure 7) in young animals' brain tissues indicates that ouabain-induced increase of $\left[\mathrm{Ca}^{2+}\right]_{i}$, which has inhibitory effect on receptors affinity to agonist, is responsible for reverse dose dependent decrease of ouabin binding in range of $10^{-11}-10^{-9} \mathrm{M}$ concentration (Figure $3 \mathrm{~A}$ ). Data on dosedependent weakening of ouabain-induced cell dehydration in range of $10^{-11}-10^{-9} \mathrm{M}$ (Figure 4), leading to increase of the number of receptors in membrane (Table 1) could serve as an evidence for this suggestion. Obtained data on age-dependent dysfunction of dose-dependent ouabain binding accompanied by inactivation of ${ }^{45} \mathrm{Ca}^{2+}$ efflux (Figure 6) and literature data on the high affinity of $\alpha_{3}$ receptors to $\mathrm{Ca}$ ions
[53] confirm also this suggestion. However, a question rises which of these two phenomena is primary. On the basis of data presented in this work we suggest that the dysfunction of $\alpha_{3} \mathrm{Na}^{+} / \mathrm{K}^{+}$pump isoform in aged animals is a consequence of $\left[\mathrm{Ca}^{2+}\right]_{\mathrm{i}}$ increase.

$10^{-4} \mathrm{M}$ ouabain, having fully inhibitory effect on $\mathrm{Na}^{+} / \mathrm{K}^{+}$pump, activates ${ }^{45} \mathrm{Ca}^{2+}$ efflux in aging animals (Figure $7 \mathrm{~A}$ ). Therefore, ouabaininduced activation of ${ }^{45} \mathrm{Ca}^{2+}$ efflux in brain cortex of old animals can be explained by release of $\mathrm{Ca}^{2+}$ by intracellular storage. It is clear that data on activation effect of ouabain on ${ }^{45} \mathrm{Ca}^{2+}$ efflux in cortex of aged rats (Figure 6) cannot be explained by ouabain-induced inactivation of $\mathrm{Na}^{+} / \mathrm{K}^{+}$pump.

Since intracellular $\mathrm{Ca}^{2+}$ buffer system is extra sensitive to external and internal signals it can be suggested as mechanism responsible for ouabain-induced elevation of ${ }^{45} \mathrm{Ca}^{2+}$ efflux in old and inactivation in young rats' brain cortex and subcortex tissues. The reason of reverse age dependency of ${ }^{45} \mathrm{Ca}^{2+}$ efflux and its ouabain sensitivity in cerebellum observed in present work stays unclear and needs a more detailed investigation.

Taking together data obtained in present work on reversal ouabain effects, especially low ouabain concentration, on intracellular $\mathrm{Ca}$ buffering systems and brain tissue hydration in young and old animals and literature data on constant circulation of endogenic ouabain like compound in blood [55], it can be concluded on possible beneficial effect of this compound on aged organisms and hazardous effect on young organisms, considering Ca-releasing from neurons in old and promotion of $\mathrm{Ca}$ enrichment process in young animal's brain. It is obvious that this suggestion can be considered as a working hypothesis which is the subject of our current study.

\section{References}

1. Ayrapetyan SN (1980) On the Physiological Significance of Pump Induced Cel Volume Changes. Adv Physiol Sc 23: 67-82.

2. Ayrapetyan SN, Arvanov VL (1979) On the mechanism of the electrogenic sodium pump dependence of membrane chemosensitivity. Comp Biochem Physiol A Physiol 64: 601-604.

3. Ayrapetyan SN, Arvanov VL, Maginyan SB, Azatyan KV (1985) Further study of the correlation between Na-pump activity and membrane chemosensitivity. Cell Mol Neurobiol 5: 231-243.

4. Ayrapetyan SN, Suleymanyan MA, Saghyan AA, Dadalyan SS (1984) Autoregulation of the Electrogenic Sodium Pump. Cell Mol Neurobiol 4: 367383

5. Ayrapetyan SN, Rychkov GY, Suleymanyan MA (1988) Effect of water flow on transmembrane ionic currents in neurons of Helix pomatia and in Squid giant axons. omp Biochem Physiol A Physiol 89: 179-186.

6. Hoffmann EK, Lambert IH, Pedersen SF (2009) Physiology of cell volume regulation in vertebrates. Physiol Rev 89: 193-277.

7. Kostyuk PG, Mironov SL, Doroshenko PA (1982) Energy profile of the calcium channel in the membrane of mollusc neurons. J Membrane Biol 70: 181-189.

8. Ayrapetyan $\mathrm{S}$, North $\mathrm{A}(2001) \mathrm{Na}^{+} / \mathrm{K}^{+}$pump and $\mathrm{Na}^{+} / \mathrm{Ca}^{2+}$ exchanger as metabolic regulators and sensors for extra weak signals in neuro membrane. Modern Problems of Cell Mol Biophy.

9. Baumgarten CM (2006) Cell volume regulation in cardiac myocytes: a leaky boat gets a new bilge pump. J Gen Physiol 128: 487-489.

10. Baker PF, Blaustein MP, Hodgkin AL, Steinhardt SA (1969) The influence of calcium on sodium efflux in squid axons. J Physiol 200: 431-458.

11. Juhaszova $\mathrm{M}$, Blaustein $\mathrm{M}(1982) \mathrm{Na}^{+}$pump low and high ouabain affinity alpha subunit isoforms are differently distributed in cells. Proc Natl Acad Sci U S A 94: 1800-1805.

12. Blaustein MP, Lederer WJ (1999) Sodium/calcium exchange: its physiological implications. Physiol Rev 79: 763-854. 
Citation: Ayrapetyan S, Heqimyan A, Nikoghosyan A (2012) Age-Dependent Brain Tissue Hydration, Ca Exchange and their Dose-Dependent Ouabain Sensitivity. J Bioequiv Availab 4: 060-068. doi:10.4172/jbb.1000114

13. Fraser $\mathrm{CL}$, Arieff Al (2001) Na-K-ATPase activity decreases with aging in female rat brain synaptosomes. Am J Physiol Renal Physiol 281: F674-F678.

14. Takeuchi A, Tatsumi S, Sarai N, Terashima K, Matsuoka S, et al. (2006) lonic Mechanisms of cardiac cell swelling induced by blocking $\mathrm{Na}^{+} / \mathrm{K}^{+}$pump as revealed by experiments and simulation. J Gen Physiol 128: 495-507.

15. Gibson GE, Peterson C (1987) Calcium and the aging nervous system. Neurobiol Aging 8: 329-343.

16. Landfield PW (1987) 'Increased calcium current' hypothesis of brain aging Neurobiol Aging 8: 346-347.

17. Wang ZM, Messi ML, Delbono O (2000) L-type $\mathrm{Ca}^{2+}$ channel charge movement and intracellular $\mathrm{Ca}^{2+}$ in skeletal muscle fibers from aging mice. Biophys $\mathrm{J} 78$ : 1947-1954.

18. Weisleder N, Brotto M, Komazaki Sh (2006) Muscle aging is associated with compromised $\mathrm{Ca}^{2+}$ spark signaling and segregated intracellular $\mathrm{Ca}^{2+}$ release. $\mathrm{J}$ Cell Biol 174: 639-645.

19. Kaplan KP, Jurkovicova D, Babusikova E, Hudecova S, Racay P, et al. (2007) Effect of aging on the expression of intracellular $\mathrm{Ca}^{2+}$ transport proteins in a rat heart. Mol Cell Biochem 301: 219-226.

20. Thibault O, Gant JC, Landfield PW (2007) Expansion of the calcium hypothesis of brain aging and Alzheimer's disease: minding the store. Aging Cell 6: 307317

21. Skou J (1957) The influence of some cations on an adenosine triphosphatase from peripheral nerves. Biochim Biophys Acta 23: 394-401.

22. Adams RJ, Schwartz A, Grupp G, Grupp I, Lee SW, et al. (1982) High-affinity ouabain binding site and low-dose positive inotropic effect in rat myocardium. Nature 296: 167-169

23. James PF, Grupp IL, Grupp G, Woo AL, Askew GR, et al (1999) Identification of a specific role for the $\mathrm{Na}$, K-ATPase $\mathrm{a}_{2}$ isoform as a regulator of calcium in the heart. Mol Cell 3: 555-563.

24. Heqimyan A, Narinyan L, Nikoghosyan A, Deghoyan A, Yeganyan A, et al (2012) Age dependency of high affinity ouabain receptors and their magneto sensitivity. The Environmentalist 32: 228-235.

25. Baker PF, Willis JS (1972) Inhibition of the sodium pump in squid giant axons by cardiac glycosides: dependence on extracellular ions and metabolism. $J$ Physiol 224: 463-475.

26. Lucchesi PA, Sweadner KJ (1991) Postnatal changes in Na,K-ATPase isoform expression in rat cardiac ventricle. Conservation of biphasic ouabain affinity. $J$ Biol Chem 266: 9327-9333.

27. Gao J, Wymore RS, Wang Y, Gaudette GR, Krukenkamp IB, et al. (2002) Isoform-specific stimulation of cardiac $\mathrm{Na} / \mathrm{K}$ pumps by nanomolar concentrations of glycosides. J Gen Physiol 119: 297-312.

28. Sweadner KJ (1989) Isozymes of the Na+/K+-ATPase. Biochim Biophys Acta 988: 185-220.

29. Therien AG, Nestor NB, Ball WJ, Blostein R (1996) Tissue-specific versus isoform-specific differences in cation activation kinetics of the $\mathrm{Na}$, K-ATPase. American Society for Biochemistry and Molecular Biology 271: 7104-7112.

30. Juhaszova M, Blaustein MP (1997) Na+ pump low and high ouabain affinity alpha subunit isoforms are differently distributed in cells. Proc Natl Acad Sci U S A 94: 1800-1805.

31. Haworth RA, Goknur AB, Bertroff HA (1989) Inhibition of Na-Ca exchange by general anesthetics. Circ Res 65: 1021-1028.

32. Heqimyan A, Deghoyan A, Ayrapetyan S (2011) Ketamine effect on tissue hydration. 4: 42-49.

33. Krnjevic K (1974) Central actions of general anesthetics. Molecular mechanisms in general anesthesia. Churchill Livingstone, Edinburgh.

34. Dipolo R and Beauge L (2006) Sodium/calcium exchanger: influence of metabolic regulation on ion carrier interactions. Physiol Rev 86: 155-203.

35. Takahashi R, Aprison M (1964) Acetylcholine content of discrete areas of the brain obtained by a near-freezing method. J Neurochem 11: 887-898.

36. Cooke KR (1978) Oubain and regulation of cellular volume in freshly prepared slices of rabbit renal cortex. J Physiol 279: 361-374.

37. Ayrapetyan SN, Suleymanyan MA (1979) On the pump-induced cell volume changes. Comp Biochem Physiol A Physiol 64: 571-575.
38. Khachaturyan ZS (1994) Calcium Hypothesis of Alzheimer's Disease and Brain Aging. Annals of the New York Acad Sci 747: 1-11.

39. Saghian AA, Ayrapetyan SN, Carpenter DO (1996) Low dose of ouabain stimulates the $\mathrm{Na} / \mathrm{Ca}$ exchange in neurons. Cell Mol Neurobiol 16: 489-498.

40. Iwasa K and Tasaki I (1982) Swelling of axon membrane during excitation. In: Membrane and Transport 2: 385-388.

41. Haussinger D (1996) The role of cellular hydration in the regulation of cell function. Biochem J 313: 697-710

42. Ayrapetyan SN (2012) Cell hydration as a universal marker for detection of environmental pollution. The Environmentalist 32: 210-221.

43. Lux HD, Heinemann U, Dietzel I (1986) lonic changes and alterations in the size of the extracellular space during epileptic activity. Adv Neurol 44: 619-639.

44. Escueta AV, Ward AA Jr., Woodbury DM, Porter RJ (Raven, New York), 619639

45. Holthoff K, Witte OW (1996) Intrinsic optical signals in rat neocortical slices measured with near-infrared dark-field microscopy reveal changes in extracellular space. J Neurosci 16: 2740-2749.

46. Darquie A, Poline JB, Poupon C, Saint-Jalmes H, Le Bihan D (2001) Transient decrease in water diffusion observed in human occipital cortex during visual stimulation. Nat Acad Sci 98: 9391-9395.

47. Warren AJ, Colledge WH, Carlton MB, Evans MJ, Smith AJ, et al. (1994) The oncogenic cysteine-rich LIM domain protein rbtn2 is essential for erythroid development. Cell 78: 45-57.

48. Miller DH, Albert PS, Barkhof F, Francis G, Frank JA, et al. (1996) Guidelines for the use of magnetic resonance techniques in monitoring the treatment of multiple sclerosis. US National MS Society Task Force. Ann Neurol 39: 6-16.

49. Wilson MM, Morley JE (2003) Invited review: Aging and energy balance. J App Physiol 95: 1728-1736.

50. D'Anci KE, Constant F, Rosenberg IH (2006) Hydration and cognitive function in children. Nutr Rev 64: 457-464

51. Parton RG, Simons K (2007) The multiple faces of caveolae. Nat Rev Mol Cell Biol 8: 185-194.

52. Montero M, Alonso MT, Albillos A, García-Sancho J, Alvarez J, et al. (2001) Mitochondrial $\mathrm{Ca}^{2+}$-induced $\mathrm{Ca}^{2+}$ Release Mediated by the $\mathrm{Ca}^{2+}$ Uniporter. Mo Biol Cell 12: 63-71.

53. Kometiani P, Liu L, and Askari A (2005) Digitalis-induced signaling by $\mathrm{Na}^{+} / \mathrm{K}^{+}$ ATPase in human breast cancer cells. Mol Pharmacol 67: 929-936.

54. Blaustein MP, Zhang J, Chen L, Song H, Raina H, et al. (2009) The pump, the exchanger, and endogenous ouabain: signaling mechanisms that link salt retention to hypertension. Hypertension 53: 291-298.

55. Ayrapetyan SN (1970) Metabolically dependent fraction of membrane potentia and electrode properties of the membrane of giant neurons in mollusks. Neurosci Behav Physiol 4: 53-57.

56. Harwood S, Yaqoob MM (2005) Ouabain-induced cell signaling. Front Biosc 10: 2011-2017. 